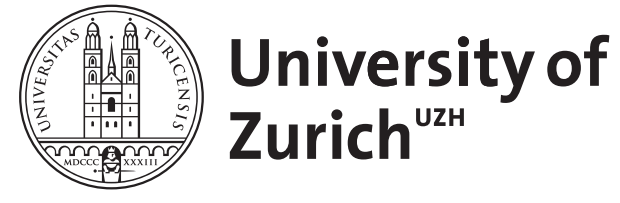

\title{
Normative reasons for Mentalism
}

Schmidt, Eva

DOI: https://doi.org/10.1007/978-3-319-93369-6_5

Posted at the Zurich Open Repository and Archive, University of Zurich ZORA URL: https://doi.org/10.5167/uzh-160064

Book Section

Accepted Version

Originally published at:

Schmidt, Eva (2018). Normative reasons for Mentalism. In: Kyriacou, Christos; McKenna, Robin. Metaepistemology : Realism and Anti-Realism. Cham: Springer, 97-120.

DOI: https://doi.org/10.1007/978-3-319-93369-6_5 


\section{Normative Reasons for Mentalism}

Eva Schmidt

The aim of this paper is to connect the traditional epistemological issue of justification with the what one might call the 'new reasons paradigm' coming from the philosophy of action and metaethics. More specifically, I will show that Conee and Feldman's mentalism, a version of internalism about justification, can profitably be spelled out in terms of subjective normative reasons. On the way to achieving this aim, I will argue that it is important to ask not just the oft-discussed ontological question about epistemic reasons - what kind of entities are they? - but also: Reasons in which sense are fundamental to justification?

My entry point is the debate between externalism and internalism, with a focus on mentalism/evidentialism (section 1). I motivate an insertion of reasons into mentalism and argue that this leads to the question of which kind of reasons are fundamental to justification (section 2). Next, I argue that mentalists should spell out their view by appeal to normative rather than deliberative or explanatory reasons (section 3 ). I then discuss how exactly mentalism with normative reasons should be elaborated (section 4) and conclude by connecting the results to a plausible version of epistemological disjunctivism (section 5).

\section{Mentalism/Evidentialism About Justification}

To say that a belief is justified is to ascribe to it a certain - the central - positive epistemic normative status. Take

\section{The vitamin C case}

I believe

(1) that vitamin $\mathrm{C}$ is water-soluble.

Moreover, I remember

(2) that I learned that vitamin C is water-soluble in high school and have the background belief

(3) that vitamin C powder (the kind available in drugstores) can be mixed with water.

In virtue of my memory (2) and my belief (3), I have ex ante justification for my belief (1) - it is suitable for me to have this belief, given these mental states. If I also base my belief (1) on my memory and my background belief, it is ex post justified (Goldman 1979, 21). Assume that (2) and (3) are the only mental states I have with any bearing on this issue. Then, my belief (1) is all-things-considered justified. 
But under which conditions is a subject's belief justified? Internalists affirm, and externalists deny, that a belief's justification depends only on factors that are given from the believer's perspective. One motivation for internalism comes from the so-called new evil demon problem (Cohen and Lehrer 1983). Imagine your non-factive mental duplicate who - unlike you is constantly deceived by an evil demon, so that her perceptual experiences, memories, and beliefs are mostly incorrect. Given that you and your duplicate reason equally well from the same experiences, memories etc., it seems that your beliefs are both equally justified. But if this is correct, then a believer's situation beyond her own mental states and processes cannot make a difference to her justification.

Correspondingly, mentalism, as one version of internalism, maintains that the justificatory status of a subject's beliefs strongly supervenes on her non-factive mental states and other mental conditions (Conee and Feldman 2001, 234). ${ }^{1}$ Mentalism is combined with evidentialism by Conee and Feldman (2004a) - the subject's mental states, as her evidence, determine the degree to which her beliefs are justified. Evidentialism has been phrased as follows:

ES The epistemic justification of anyone's doxastic attitude toward any proposition at any time strongly supervenes on the evidence that the person has at the time. (Conee and Feldman 2004b, 101 (Afterword))

EJ Doxastic attitude D toward proposition $\mathrm{p}$ is epistemically justified for $\mathrm{S}$ at $\mathrm{t}$ if and only if having $\mathrm{D}$ toward $\mathrm{p}$ at $\mathrm{t}$ fits the evidence that $\mathrm{S}$ has at $\mathrm{t}$. (Conee and Feldman $2004 b, 83)^{2}$

(ES) makes a strong supervenience claim: The dependence of justification on evidence is such that even across possible worlds, subjects who have the same evidence (mental states) have the same justification for their beliefs. This claim ensures that the new evil demon problem doesn't affect evidentialism, but note that it is quite weak: It allows that non-mental phenomena that don't vary between possible worlds fix justificatory status. Conee and Feldman claim that evidence/mental states determine justification, but worries have been raised about whether supervenience can be used to express such a dependence claim (McLaughlin and Bennett 2018).

\footnotetext{
${ }^{1}$ I focus on non-factive mental states and duplicates throughout.

${ }^{2}$ To focus the discussion, I will restrict myself to a thesis about the justification of belief, rather than doxastic attitudes generally. Since it plays no role for my argument, I will spend no time on the claim involved in (ES) and (EJ) that only concurrent evidence makes a difference to justification.
} 
(EJ), on the other hand, is a biconditional: A belief is justified if and only if it fits, or is supported, by the subject's evidence/mental states. "Fit" can spelled out in different ways, for instance, as saying that the probability of the truth of the belief is raised by the evidence. ${ }^{3}$

Next, (ES) and (EJ) are concerned with ex ante and all-things-considered, or overall justification. They don't say whether the subject also bases her belief on her evidence - whether it is ex post justified. And her evidence includes all of her mental states. But what exactly is the subject's evidence? Seeing as we're looking at a combination of mentalism and evidentialism, a subject's evidence consists of the information that she has and can operate on immediately in forming beliefs or, put somewhat differently, her beliefs, memories, experiences, and other mental states. (Conee and Feldman 2008, 88.)

Let me now show how to connect this to the reasons paradigm.

\section{Reasons for Mentalism}

It can be argued that the subject's evidence is identical with her epistemic reasons. First off, it is widely held that 'evidence' and 'epistemic reason' are more or less synonymous (Kelly 2014). In most, if not all cases of belief, 'epistemic reasons' talk and 'evidence' talk can't be used interchangeably. Conee and Feldman seem to agree (cf. their $(2008,85)$ and $(2004 c, 1)$ ), as does McCain $(2014,10)$, another evidentialist. This identity can be further supported by noticing that evidence just is what bears on the justification or reasonableness of a belief (Goldman 2011, 255) ; but so are epistemic reasons (Gibbons 2010, 344). Finally, what distinguishes epistemic reasons from practical reasons is that only the former bear positively on the truth of the beliefs they support. Evidence, as something that indicates that a belief is true, has just the kind of connection to truth that is specific to epistemic reasons. ${ }^{5}$ So we should identify the two.

If this is correct, mentalists/evidentialists should accept mentalism with reasons:

R-Mentalism: A subject's belief that $p$ is epistemically justified if and only if (and because) the subject has epistemic reasons, overall, for believing that $p$.

Let me clarify. R-Mentalism is restricted to the case of belief; it leaves out the temporal di-

\footnotetext{
${ }^{3}$ Note that Conee \& Feldman (2008) instead appeal to explanatory relations.

${ }^{4}$ Conee and Feldman (2011) are not too happy with this suggestion, which Goldman uses to argue that their view is circular - but in response, they appeal to encyclopedia entries which, again, equate evidence with grounds or reasons.

${ }_{5}^{5}$ I have defended the view that there is a broader gap between practical reasons and evidence. See Schmidt (2017a).
} 
mension; and it is concerned with all-things-considered ex ante justification. It incorporates the idea from (EJ) that one has justification for a belief just in case one's belief fits one's allthings-considered evidence/reasons, but without mentioning 'fit' explicitly. That a subject has reasons, overall, for believing that $p$, just is to say that so believing fits with her reasons.

Next, in reaction to the aforementioned worries about the supervenience claim from (ES), RMentalism incorporates a "because"-claim instead. R-Mentalism is thereby stronger than mentalism/evidentialism - a subject's beliefs are justified in virtue of the reasons that she has, where this may be understood as a grounding claim (cf. Schmidt 2017b). R-Mentalism is a kind of mentalism as long as the grounding facts, i.e. facts about reasons possession, are mental facts, which can be tested by confronting it with the new evil demon problem. ${ }^{6}$

Even if you reject the identification of evidence with reasons, ${ }^{7}$ note that it is useful to see what would follow from endorsing R-mentalism. To begin with, there hasn't been much in-depth exploration of how the reasons paradigm relates to traditional epistemological positions. Moreover, even if R-Mentalism and mentalism/evidentialism are genuinely distinct views, they are still close relatives. By getting clear on how the former is best developed, we can probably draw conclusions about the latter as well.

One such conclusion concerns the nature of evidence. As Kelly (2014) points out, 'evidence' is a multi-faceted term that can, e.g., be understood as that which justifies belief, that which indicates the truth of a proposition, or as something that rational subjects heed. Moreover, Conee and Feldman (2008) sometimes speak of mental states and sometimes of propositions or contents as evidence; in their $(2011,303)$, they even once identify evidence with facts. Introducing R-Mentalism allows us to tap the resources of the debate over the nature of reasons so as to gain some clarity here.

One might object that, as a matter of fact, epistemologists have discussed the question of what evidence and epistemic reasons consists in - facts, propositions, or mental states. ${ }^{8}$ So maybe to gain clarity on the nature of evidence/reasons, it is sufficient to turn to this literature. There is no need either to delve into the complicated debate over practical reasons or to accept RMentalism.

I disagree. Determining the nature of the mentalist's evidence does not yet settle a further important question concerning mentalism, which requires the reasons idiom: Should the reasons

\footnotetext{
${ }^{6}$ One get-out strategy for mentalists/evidentialists is to reject the move from supervenience to grounding. Because of limited space, I cannot further motivate the grounding claim, so I here merely acknowledge that my proposal is indeed stronger than the original mentalist/evidentialist claim.

${ }^{7}$ Cf. Littlejohn (2013) and Sylvan \& Sosa (forthcoming).

${ }^{8}$ See Williamson (2000), Neta (2008), Turri (2009), Littlejohn (2012), McCain (2014), Hawthorne \& Magidor (forthcoming), among others.
} 
which give rise to epistemic justification be understood as reasons in an explanatory, a deliberative, or a normative sense?

Let me briefly introduce these kinds of reasons for action..$^{9}$ Normative reasons are considerations that count in favor of an agent's $\varphi$-ing or that justify her $\varphi$-ing, even if the agent is not aware of them. Take the following example.

\section{The hiker and the snake}

A hiker in the desert comes upon a snake, which will bite her unless she remains immobile. The hiker has learned from a reliable source, and thus believes

(4) that the snake will bite unless she turns and runs.

She turns and runs. (Cf. Parfit 2011)

That the snake will bite the hiker unless she remains immobile is a normative reason for the hiker to remain immobile. Explanatory reasons, by contrast, are reasons that explain why the agent $\varphi$-s, the beliefs or desires that cause as well as make the agent's $\varphi$-ing rationally intelligible (Davidson 1980). For instance, the hiker turns and runs because she believes (4) and desires not to be bitten, which explains her action and makes it rationally intelligible. Finally, deliberative reasons are the reasons in the light of which an agent $\varphi$-s. These are the considerations that she weighs or takes into account as she makes up her mind to $\varphi$, and which persuade her to $\varphi$. In the example, it is considerations such as (4) in the light of which she turns and runs.

Two important observations concerning explanatory and deliberative reasons: First, there is a close match between them, though the former come into view from a third-person perspective and the latter from a first-person perspective. It is exactly the considerations that are available to the agent as the contents of her rationalizing mental states in whose light she acts. Vice ver$s a$, her mental states rationalize her action exactly because they have a content in whose light the action seems the thing to do.

Second, explanatory and deliberative reasons, so understood, provide ex post explanations, but also an ex ante understanding of the agent. Her beliefs and desires determine which courses of action available to her would be rationally intelligible. Correspondingly, if we know the considerations available to the agent, we can tell which action will antecedently seem to her to be the one to perform in light of these considerations.

The three varieties of reasons reflect different, yet mutually compatible ways in which we

${ }^{9}$ Cf. Hieronymi 2011, Mantel 2018, Olson and Svensson 2005, Alvarez 2017, among many others. 
employ 'reasons' talk, and can naturally be adapted to the case of belief. First, normative epistemic reasons are considerations that count in favor of adopting a certain belief. Second, explanatory epistemic reasons are used in explanations that cite the mental states that cause someone to form a belief and that rationalize her believing so. Third, deliberative reasons make a belief intelligible by providing the considerations that persuade the believer to adopt her belief.

The importance of these distinctions derives from the fact that even the question, 'What is the nature of evidence?', doesn't touch upon the issue of whether justification is normative bedrock, according to mentalism. That is, merely figuring out whether evidence consists in mental states or propositions, say, doesn't help with the question whether justification is the first and fundamental normative epistemic standing, or whether there are other, more basic, normative epistemic phenomena, to which justification can be traced back. However, if we endorse R-Mentalism and ask, 'Are the reasons appealed to by mentalism normative reasons, explanatory reasons, or deliberative reasons for belief?', we ask whether the reasons that determine the justification of a subject's beliefs are themselves already normative, or whether they are non-normative, merely explanatory or deliberative reasons. Is mentalism a view on which epistemic normativity begins with justification (to which reasons as a purely descriptive factor give rise) or one on which it begins with epistemic normative reasons?

Two remarks before addressing these questions. First, philosophers of action will balk at the suggestion that epistemic justification goes back to non-normative reasons. On the accepted picture, actions are justified in virtue of normative reasons by definition, and the same has to hold for belief. However, traditional mentalism can be understood as the claim that certain non-normative phenomena determine justification. This understanding is available even if we combine mentalism with reasons rather than evidence, at least given that there is a purely descriptive notion of epistemic reasons. (I will defend this possibility in the next section.) In this context, note further that Conee and Feldman $(2001,239)$ deny that "epistemic concepts are to be analyzed in ... deontological terms." Rejecting a connection between justification and normative reasons would fit well with their negative attitude concerning epistemic obligations.

Second, these options for mentalism bear on the issue of meta-epistemological anti-realism (Kyriacou 2016). If spelled out as appealing to merely explanatory or deliberative reasons, RMentalism makes room for an elimination of normative reasons altogether, and thus for a very strong kind of anti-realism. For recall that explanatory and deliberative reasons are supposed to be reasons in a merely descriptive sense. Even if she appeals to normative reasons, the 
mentalist is under pressure to accept a kind of mind-dependence of epistemic normativity: Mentalism involves the claim that the facts about the reasons that the subject possesses are mental facts. This suggests that normative reasons are dependent, for their existence, on the subject's (but not thereby on an external appraiser's!) mental states. As will become clear below, this can be either because a normative reason consists in the fact that the subject has certain mental states, or because a consideration is a normative epistemic reason only once it is the content of one of the subject's mental states. On some views, this mind-dependence is sufficient to make R-Mentalism a kind of anti-realism because there are then no facts about normative reasons independent of our mental states (Street 2010).

Now, let's look at combinations of R-Mentalism with deliberative, explanatory, and normative reasons.

\section{Which Kind of Reasons for R-Mentalism?}

In this section, I discuss varieties of mentalism that result from plugging in different kinds of reasons into R-Mentalism, while holding on to the central mentalist assumption - brought out by the new evil demon problem - that changes beyond the believer's mind make no difference to her justification.

Here's how to identify R-mentalism's reasons with deliberative reasons - the contents of her mental states. In the vitamin $\mathrm{C}$ case, it is suitable for me to believe (1), that vitamin $\mathrm{C}$ is water-soluble, in the light of the remembered consideration (2), that I learned this in school, and the consideration that vitamin $\mathrm{C}$ powder can be mixed with water, the content of my background belief (3). These are my deliberative reasons, which I take to bear positively on whether to believe (1). Plausibly, my belief (1) is ex ante justified because of how the situation presents itself to me.

Here is the proposal:

D-Mentalism: A subject's belief that $p$ is epistemically justified if and only if (and because) the subject has deliberative epistemic reasons, overall, for believing that $p$.

In other words, where (and because)the subject's available deliberative reasons present her with a situation which, all things considered, bears positively on the belief that $p$, the latter is justified. As is proper for a mentalist view, the same holds for any possible subject who has the same deliberative reasons.

A lot rides on how we spell out the idea that (the subject takes it that) the considerations bear 
on whether to adopt the belief. To illustrate this, say that I don't remember (2) and that, rather than believing (3), I believe

(5) that vitamin $B$ powder can be mixed with water.

Imagine that I am a bit confused today and that I take consideration (5) to have a positive bearing on whether to believe (1), so that I would form this belief in the light of (5). But certainly, despite this, my belief (5) does nothing to justify my belief (1).

To avoid this problem, D-Mentalism needs to make deliberative reasons more demanding than they initially appear. When a subject takes a consideration to bear on whether to adopt a belief, she treats the consideration as a normative reason - it is an apparent normative reason for her (Parfit 2011, 35). Accordingly, among the considerations that would persuade the subject to adopt a belief, only those which would be normative reasons to form the belief were they true, count as deliberative reasons. This would be to supply the mentalist's notion of a deliberative reason with an account of substantial rationality, which subjects exhibit who are responsive to what their reasons are reasons for. (Substantive rationality allows for factual mistakes, but not for mistakes about what one's reasons favor.)

Unfortunately, on this proposal, D-Mentalism loses its special interest of providing a completely descriptive foundation for epistemic justification. While deliberative reasons are not themselves normative - merely apparent normative reasons only appear to have normative force - they do conceptually presuppose the notion of a normative reason. For any 'bad' case, in which there is a merely apparent reason for the subject to believe that $p$ because she is mistaken about an empirical fact, there is a possible 'good' case in which she is in touch with the facts and her mental states are correct. Her deliberative reason will then also be a normative reason to believe that $p$, and will contribute to the explanation of the belief's justification. But then normative reasons are fundamental to justification, sometimes because they are directly involved, sometimes because our conception of apparent reasons presupposes them. ${ }^{10}$ Here's an additional problem: The same content can be believed, desired, imagined, etc. (cf. Turri 2009). So, it may be that I merely imagine that vitamin C powder can be mixed with water. Obviously, if this is the only consideration available to me that has a bearing on my belief (1), the latter is not justified even though the consideration is an apparent reason for believing (1). In response, we can restrict deliberative reasons to the contents of presentational attitudes with an assertoric character - only these contribute to justification (Schroeder

10 Contrary to my suggestion above that deliberative reasons are naturally incorporated into an anti-realist view, D-Mentalism would then be a realist position: It would presuppose the existence of mind-independent normative reasons after all. 
2008). But this can't be right either, for my non-assertoric imagining that vitamin $\mathrm{C}$ powder can be mixed with water (or my feeling of queasiness, which has no consideration as its content) do justify beliefs about them, viz. my belief that I am imagining that vitamin $\mathrm{C}$ powder can be mixed with water (or that I feel queasy) (Conee and Feldman 2008, 87). Here, it is plausibly the mental state as a whole (including its content or phenomenal character) which is a reason for the subject to believe that she is in the state, and in virtue of which her belief is justified. But then D-Mentalism can't be correct - it is not only her available considerations that contribute the subject's justification, but also her mental states.

Rather than looking for further defenses of D-Mentalism, I take this as sufficient motivation to turn to mentalism with explanatory reasons. For there is a close parallelism between deliberative and explanatory reasons anyway (cf. section 2). ${ }^{11}$ Moreover, E-Mentalism is concerned with mental states as individuated by their contents or their phenomenal character, for otherwise we cannot see how a subject's mental states, taken together, can rationalize her belief with its particular content. So, E-Mentalism doesn't exclude mental contents from being constitutive of epistemic reasons and justification, it merely insists that the former don't exhaust a subject's reasons.

Here is the view:

E-Mentalism: A subject's belief that $p$ is epistemically justified if and only if (and because) the subject has explanatory epistemic reasons, overall, for believing that $p$.

To illustrate: My memory (2) and my background belief (3) are mental states that would make my believing (1) rationally intelligible. So, my belief (1) is ex ante justified. Moreover, it is justified because of my mental states, and mutatis mutandis for my mental duplicates - so, this is a version of mentalism.

E-Mentalism is very close to Conee and Feldman's intended view: It ascribes a central justificatory role to mental states - they themselves are the reasons. It can allow for them to determine a belief's justificatory status even if they are not presentational attitudes, or don't have a (consideration as their) content. For instance, my imagining that vitamin $\mathrm{C}$ powder can be mixed with water would rationalize my belief that this is what I imagine (but not my belief (3) that vitamin $C$ powder can be mixed with water).

As above, more needs to be said about what is involved in rationalizing a belief. For it can

\footnotetext{
${ }^{11}$ With one significant difference, though: More entities come into view as reasons if we turn to explanatory reasons, for these aren't restricted to presentational attitudes that have considerations as their contents.
} 
look like my belief (5), that vitamin $B$ powder can be mixed with water, together with my confusion, does make my belief (1) rationally intelligible. We can fully understand why I would make the (unwarranted) transition to (1). But, the E-Mentalist can reply, that doesn't make the transition rational. To make this response stick, however, she needs to provide us with an account of what makes belief rational.

An appeal to substantial rationality would once again force her to involve normative reasons in her attempt to capture the basis of justification. The contrast of E-Mentalism with mentalism with normative reasons would be lost. A better option, which fits quite nicely with the idea of rationalizing explanations, is to appeal instead to structural rationality. ${ }^{12}$

Structural rationality is the kind of rationality that a person exhibits when her mental states cohere with each other. For instance, the structurally rational believer doesn't believe that $p$ and believe that not- $p$, nor does she believe that she has insufficient evidence to believe that $p$ while believing that $p$ (e.g. Broome 1999). Some philosophers argue that structural rationality is itself normative, but many oppose this idea (e.g. Broome 2008). E-Mentalists could join the latter camp. The result would be a view akin to coherentism: A belief is justified for a subject if and only if (and because) an explanation of the belief is available which appeals to its coherence with the subject's pre-existing mental states. For instance, my memory (2) and belief (3) would rationally explain my belief (1) in that an adoption of the latter would cohere with (2) and (3). My belief (1) is therefore justified. If we make our coherence requirements rich enough, by contrast, my belief (1) wouldn't be rationalized by my belief (5), that vitamin B powder can be mixed with water. For, plausibly, it is structurally irrational to adopt a belief like (1) out of thin air, without having any other attitudes from which one might infer to it.

I believe that this is the best available version of R-Mentalism that builds epistemic justification from purely descriptive phenomena. It may seem surprising to first deny that rationality is normative, and then to claim that it gives rise to the normative epistemic standing of justification. However, this is unproblematic. For one, this is just one way of capturing the idea that the normative supervenes on the descriptive. For another, the E-Mentalist might interpret 'justification' as an evaluative status of a belief. Explanatory reasons are things that make things reasonable - they are the attitudes that cohere with the belief in question and thus show how it is rational. This, in turn, is fundamental to the positive evaluation of the belief as justified. Unfortunately, E-Mentalism faces some major difficulties. It disconnects a belief's justification from its truth - it doesn't show how justification is truth-conducive, even though what is

\footnotetext{
12 There is a third option, which I cannot address here: Appealing to a purely subjective notion of rationality (Foley 1987).
} 
particular about epistemic (rather that moral or pragmatic) justification is that it is a normative standing which flows from belief's connection with truth. That her mental states cohere with each other and that she is thus structurally rational is a feature of the subject that doesn't touch upon her connection to the world, to whether she is sensitive to the way things really are. Relatedly, this renders it obscure what distinguishes epistemic from practical structural rationality: If we cannot appeal to justification's connection with truth, how are we to tell which coherence requirements are are needed for epistemic rationality and thus justification, and which ones concern practical rationality? For instance, E-Mentalism risks the implausible result that akrasia undermines a subject's epistemic justification.

There are two sub-difficulties which articulate this general worry in different ways. First, an explanatory reason's truth makes no difference to how good it is as a reason. Whether my belief (3) or my memory (2) are true, or whether I believe falsely or misremember, does not impede belief (3) and memory (2)'s roles as reasons that explain why, assuming I'm structurally rational, I would believe (1). But intuitively, true reasons are better than false ones; that my reasons are true typically means I'm in touch with the world. This relates to the truthconnection: When my reasons are true, believing according to them gives me pretty good chances that beliefs justified by these reasons will also be true. Not so when my reasons are false. Something appears to be defective about them. E-Mentalism cannot capture this intuition.

Second, E-Mentalism is vulnerable to opponents who claim that internalists are concerned with rationality, but not with the central epistemic standing, justification. For instance, Littlejohn (2012) and Sylvan (2014) suggest that internalism can at best provide an account of 'excusable' belief. That the subject was (structurally) rational is to say that she exhibited no faulty dispositions in reaching her belief, so if her belief is mistaken, this is excusable. However, this falls short of the belief having the genuinely positive epistemic standing of justification. Similarly, Plantinga (1990) argues that internalist 'justification' is not the central epistemic ingredient to knowledge. Applying this to E-Mentalism, adding structural rationality to true belief doesn't result in knowledge.

The strength of such criticisms, when applied to E-Mentalism, derives from the distance between structural rationality and truth. Her structural rationality doesn't bring the believer close enough to epistemic success/truth. It seems as if this way of spelling out justification indeed misses the point.

To sum up, both D-Mentalism and E-Mentalism face severe problems. On the one hand, there is the difficulty of correctly delineating the subject's epistemic reasons, e.g. excluding justifi- 
cation by merely imagining something, while allowing for justification of beliefs about one's own mental states. On the other hand, there is the problem of the notion of rationality needed to ensure that not any mental state that would persuade a subject counts as a reason. If we appeal to substantial rationality, we include normative reasons in the foundation of justification and thus fail to provide a non-normative alternative to mentalism with normative reasons; but if we appeal to structural rationality, our notion of justification is (too) disconnected from truth. So, while there is conceptual space for mentalism that incorporates non-normative reasons, no such version is after all defensible. Mentalism with normative reasons is the only game in town. I turn to varieties of this view next.

\section{Varieties of Mentalism with Normative Reasons}

Normative reasons for belief are facts that count in favor of the subject's adopting certain beliefs. Since we are looking for a mentalist account, the relevant facts can't go beyond the subject's mind. This suggests that normative reasons consist in facts about the subject's own mental states, as formulated by mentalism with mental state facts as normative reasons:

M-Mentalism: A subject's belief that $p$ is epistemically justified if and only if (and because) the fact that she has mental states $m, n, \ldots$ is a normative reason, overall, for her to believe that $p$.

In the vitamin $\mathrm{C}$ case, the fact that I remember (2) and believe (3) counts in favor of my believing (1). Therefore, my belief (1) is justified. By contrast, that I believe (5), that vitamin B powder can be mixed with water, does not count in favor of my believing (1); the belief is not thereby justified. Importantly, the fact about the subject's mental states includes all her mental states; that she has all of them counts in favor or her believing that $p$, and in virtue of this, her belief is justified. Thereby, M-Mentalism is clearly a mentalist account.

The fact that the subject has certain mental states counts in favor of her adopting a certain belief. It is appropriate for the subject to form certain beliefs, given that she has certain other mental states. This could naturally be spelled out by appeal to coherence requirements, if contrary to what I assumed in the discussion of E-Mentalism - we think that structural rationality is normative: It gives rise to normative reasons to adopt certain beliefs.

A worry for this account is that, by restricting normative reasons to mental state facts, it implausibly limits what, as a normative reason, determines a belief's justification. It conflicts 
with our practice of citing worldly facts rather than the fact that we have certain attitudes (regarding these facts) as normative reasons to believe. What justifies my belief (1)? The fact (2) that I learned it in school and the fact (3) that vitamin C powder can be mixed with water. What I'm going by in adopting my belief is the facts that my mental states represent, not the fact that I have these mental states. M-Mentalism makes it look as though only structural rationality, or coherence between mental states, provides normative reasons and thus justification for belief. But on our ordinary conception, the world beyond our mind also favors certain beliefs. Plausibly, this is so because worldly facts can make it probable that a belief is true. For instance, given that I learned this in school, it is extremely likely that vitamin $\mathrm{C}$ is indeed water-soluble. So, we should allow that worldly facts that reliably indicate that a belief is true are epistemic normative reasons and help determine a belief's justification. M-Mentalism, since it excludes this highly plausible possibility, should be abandoned. ${ }^{13}$

Here's a proposal that takes the facts that our mental states represent as the normative reasons that determine which beliefs are justified for a subject, mentalism with objective normative reasons:

O-Mentalism: A subject's belief that $p$ is epistemically justified if and only if (and because) the facts represented by her mental states, overall, count in favor of her believing that $p$.

In the vitamin C case, I have justification for my belief (1) if and only if my memory (2) and my belief (3) represent normative reasons, overall, for me to adopt this belief. They do: The fact that vitamin $\mathrm{C}$ powder can be mixed with water reliably indicates that vitamin $\mathrm{C}$ is watersoluble, as does the fact that I learned this in school. So, these facts count in favor of so believing, and my belief (1) is justified in virtue of this.

Unfortunately, O-‘Mentalism' isn't a kind of mentalism: It's not (just) in virtue of the subject's mental states that her beliefs are justified. Duplicates don't necessarily have the same justification. Consider:

\section{The vitamin $C$ duplicate case}

Unlike me, my duplicate lives in a world in which vitamin $C$ powder cannot be mixed with water. Neither of us remembers (2), but we both believe (1) and (3).

\footnotetext{
${ }^{13}$ Plausibly, to possess reasons, one has to have certain mental states no matter what, but nonetheless the nonmental facts may be the reasons. Cf. Schmidt 2017 b.
} 
My belief (1) is justified, for my belief (3) represents the fact that vitamin C powder can be mixed with water, which is a normative reason to believe that vitamin $\mathrm{C}$ powder is watersoluble. In my duplicate's world, however, it is not the case that vitamin C powder can be mixed with water. So, her belief (3) doesn't represent a fact that counts in favor of her adopting (1); her belief (1) is not justified. The justificatory status of our beliefs (1) is not the same even though we are duplicates. For O-'Mentalism', then, a subject's belief isn't justified entirely in virtue of her mental states, so this proposal cannot be used to spell out mentalism.

But there is a version of mentalism in the vicinity. We merely have to allow that not just the facts, but also the merely apparent facts represented by a subject's presentational attitudes may be normative reasons. For this, we can appeal to Schroeder's (2008) subjective normative reasons, considerations - but not necessarily facts - from the subject's perspective, that speak in favor of her $\varphi$-ing. These are merely apparent normative reasons (cf. section 3), relating to substantial normativity, except that on Schroeder's picture, they involve genuine normativity. Given that the world appears to her in a way that favors $\varphi$-ing, it is rational for her to $\varphi$. We expect her to $\varphi$ and think that, in the light of the information available to her, she ought to $\varphi$. To illustrate, if the hiker justifiably believes (4), that the snake will bite her unless she turns and runs, she has a subjective normative reason to turn and run. Given what she believes, she would be crazy to stand still (or at least irrational and hard to make sense of). Nonetheless, there is an objective normative reason for her not to move: The fact that the snake will only bite if she turns and runs objectively counts in favor of her remaining immobile. Making room for these two kinds of normative reasons allows us to make full sense of the hiker's normative situation, of a sense in which she ought to turn and run and of a sense in which she had better not move.

We can then introduce mentalism with subjective normative reasons:

S-Mentalism: A subject's belief that $p$ is epistemically justified if and only if (and because) the apparent facts represented by her mental states, overall, count in favor of her believing that $p$.

Certain facts appear to obtain to the subject, viz. those that her presentational attitudes, such as belief and perceptual experience, represent. Given these apparent facts, which constitute the situation that the subject takes herself to be faced with, there are beliefs that are substantially rational for her to form, and these beliefs are ones that she ought to have or that she has 
subjective normative reasons to adopt. These are the beliefs for which she has justification. ${ }^{14}$ The vitamin C duplicate case causes no trouble for S-Mentalism. With respect to our subjective normative reasons, my duplicate and I are in the same boat: Given that we both labor under the assumption that vitamin $\mathrm{C}$ powder can be mixed with water, it is rational for us to believe (1). The apparent fact that belief (3) presents us with is a subjective normative reason for both of us to believe (1). In virtue of this, both of us have equal justification to believe (1).

But here is a more problematic case.

\section{The berries case}

My duplicate and I both see

(6) that there are such-and-such berries on that bush.

We both have a disposition to form the belief

(7) that there are edible berries on that bush

immediately on the basis of experiencing (6), for the berries just 'look' edible to us. In my world, berries of this kind are edible, but in my duplicate's world, they are poisonous. The fact (6), represented by my experience, reliably indicates that there are edible berries on the bush, but not so the fact (6) represented by my duplicate's experience.

The trouble for S-Mentalism is that I have justification for belief (7), as for me the perceived fact (6) makes it probable that (7) is true and thus is a normative reason to believe (7). But my duplicate lacks such justification because in her world what she perceives, that there are suchand-such berries on that bush, doesn't reliably indicate (7) and so is no reason. So, my duplicate and I differ with respect to the justification of our respective beliefs (7).

To reply, in order to have justification, the subject needs to possess the relevant normative reasons. It is not sufficient that the subject's mental states represent apparent facts that favor so believing. To possess reasons, she also has to be able to be guided by the subjective normative reason to an appropriate belief (cf. Sylvan 2015). So, if my duplicate and I are both clueless about whether berries of this kind are edible, neither of us is sensitive to the fact that there are berries in the bush as a reason to believe (7). Neither of us then possesses (6) as a reason to believe (7), and neither of our beliefs is justified. This fits with everyday judgments

\footnotetext{
${ }^{14}$ Just like D-Mentalism, S-Mentalism faces the problem that not any kind of mental state - e.g. an imagining that represents a subjective normative reason adopt a belief makes a difference to its justification. It can be solved by restricting the mental states in S-Mentalism to presentational attitudes. Regarding beliefs about one's own mental states, the correct account is indeed M-Mentalism. The fact that the subject has a mental state is a normative reason for her to believe that she does.
} 
about reasons and justification. Imagine an elderly lady looking at someone pulling the trigger on a paint ball gun that is pointed at her - she has a presentational attitude representing a normative reason to believe that she will be marked with paint. If she is clueless about such things, however, we would not say that she possesses a reason, or has justification for this belief.

But maybe in the berries case, I possess (6) as a reason, but my duplicate doesn't? After all, only I am guided by my experience to the correct belief. In response, if I have the capacity to be guided by subjective normative reasons, i.e., by apparent facts, so does my duplicate. For there are no differences between duplicates with respect to their apparent reasons, and so both my duplicate and I either have or lack the competence to move from appearances as of edible berries to the belief that these berries are edible. This is compatible with the fact that in my duplicate's case, appearances were deceiving.

This leads to an improved version of S-Mentalism,

S-Mentalism*: A subject's belief that $p$ is epistemically justified if and only if (and because) the subjective normative reasons she possesses, overall, count in favor of her believing that $p$.

All in all, of the three proposals discussed in this section, O- 'Mentalism' fails as a version of mentalism since it does not guarantee that facts about reasons possession are exclusively mental facts. M-Mentalism is implausible because it limits the normative reasons relevant to justification to mental state facts. This leaves S-Mentalism* as the best version of R-Mentalism. ${ }^{15}$

\section{Results}

The idea with which I started is that the close ties between evidence and epistemic reasons, together with the openness of mentalism with respect to the kind of reasons we insert, allows us to spell out the view in interestingly different ways, even in such a way that the relevant reasons are non-normative. This should give reasons theorists who try to transfer their views from the practical realm to epistemology pause: We cannot automatically get from normative reasons as the foundation of practical justification to normative reasons as the basis of epistemic justification. More work has to be done to show that the practical picture can be transferred, one-to-one, to epistemology.

\footnotetext{
${ }^{15}$ Again, it should be combined with M-Mentalism to account for the justification of our beliefs about our own mental states.
} 
Here, I have done so by arguing that the only way to keep the reasons involved in Rmentalism non-normative disrupts the connection between justification and truth: If we take reasons as rationalizers, and rationality as mere structural rationality, we end up with reasons that are not truth-conducive. But if we understand reasons as apparent reasons, we put normative reasons at the foundations of justification after all.

It may seem that my discussion of different versions of mentalism has been unfair. On the one hand, won't mentalists be able to resist my argument by sticking with evidence instead of reasons? On the other hand, doesn't my proposal, in which S-Mentalism* is the central pillar of mentalism, also face the problem that it severs the truth-connection? I will close the paper by addressing these two worries.

As to the first worry, I concede that the mentalist/evidentialist can dig in her heels and insist that evidence is the basis of justification, while denying that this commits her to reasons in any of the senses discussed here. Still, my discussion, together with the ambiguity of 'evidence', puts the burden on my opponent to clarify her notion of evidence, and its relation to epistemic reasons, in order to ensure that it does not so commit her.

As to the second worry, traditional versions of internalism like E-Mentalism explicate justification by appeal to the limited information that is available to the subject independently of her external situation. They can neither account for the truth-connection nor give epistemic priority to the good case in which the subject is in touch with the world. S-Mentalism*, by contrast, takes as its base case one in which the subject is presented with facts that count in favor of adopting a belief (they actually indicate its truth). From such objective normative reasons, it derives what the subject has subjective normative reason to believe - and is hence justified to believe - in indistinguishable cases where these facts are merely apparent. In this sense, then, S-Mentalism* gives priority to the good case. It thereby makes room for a truth-connection: Justification connects to the truth in that it is due to one's subjective normative reasons - apparent facts that derive their normative strength from their objective 'twins' (i.e., the corresponding objective normative reasons that $d o$ make the belief's truth probable).

An additional advantage of S-Mentalism* that is thrown into relief by contrast with EMentalism is that it can be combined with an externalist view along the lines of O'Mentalism', resulting in a kind of epistemological disjunctivism (cf. Hornsby 2008; Schroeder 2015). Objective and subjective normative reasons are not mutually exclusive. Rather, we can use these two types of reasons to highlight different aspects of how the subject's situation bears on what she had better believe - on the one hand, the subject's actual situation, which favors certain beliefs, so that her justification is best when she is in touch with these 
objective normative reasons. On the other hand, the subject's situation, as she takes it to be, subjectively favors her believing certain things. Plausibly, reasons of both kinds bear on the justification of her beliefs.

Such an epistemological disjunctivism is then clearly a realist view of normative reasons. Both the way it spells out subjective normative reasons and the combination of S-Mentalism* with O-'Mentalism' rely on the existence of mind-independent objective normative reasons. If mentalism is understood along these lines, the contention that internalism fails to address the central epistemic normative standing - justification - is misguided. The subject's subjective normative reasons, thanks to their close connection with their objective 'twins', allow for her to have beliefs that are not just excusable, but genuinely epistemically proper. Nonetheless, the contrast with objective normative reasons brings out a respect in which the justification provided by S-Mentalism falls short of epistemic success: That I have subjective normative reasons does not yet guarantee that I am in touch with the world.

I thank Chrisoula Andreou, Vuko Andrić, Kevin Baum, Christoph Fehige, Susanne Mantel, Jean Moritz Müller, Stephan Padel, Katia Samoilova, Kurt Sylvan, Christian Wendelborn, Ulla Wessels, and Hong Yu Wong for helpful suggestions on this paper.

\section{References}

Maria Alvarez (2017). Reasons for Action: Justification, Motivation, Explanation. In Edward Zalta (ed.), The Stanford Encyclopedia of Philosophy (Winter 2017 Edition), URL = $<$ https://plato.stanford.edu/archives/win2017/entries/reasons-just-vs-expl/>.

John Broome (1999). Normative Requirements. Ratio 12: 398-419.

(2008). Is Rationality Normative? Disputatio 11: 153-171

Stewart Cohen and Keith Lehrer (1983). Justification, Truth, and Coherence. Synthese 55: 191-207.

Earl Conee and Richard Feldman (2001). Internalism Defended. In Hilary Kornblith (ed.), Epistemology: Internalism and Externalism. Blackwell, 1-18.

-------- (eds.) (2004a). Evidentialism: Essays in Epistemology. Oxford University Press. (2004b). Evidentialism. In ------- (eds.), Evidentialism: Essays in Epistemology. Oxford University Press, 83-107.

------- (2004c). Introduction. In ------- (eds.), Evidentialism: Essays in Epistemology. Oxford 
University Press, 1-7.

(2008), Evidence. In Quentin Smith (ed.), Epistemology: New Essays. Oxford: Oxford University Press, 83-104.

------- (2011), Replies. In Trent Dougherty (ed.), Evidentialism and its Discontents. Oxford University Press, 283-323.

Donald Davidson (1980). Actions, Reasons, and Causes. In ------ (ed.), Essays on Actions and Events. Clarendon Press, 1-19.

Richard Foley (1987). The Theory of Epistemic Rationality. Cambridge, MA: Harvard University Press.

John Gibbons (2010). Things That Make Things Reasonable. Philosophy and Phenomenological Research 81: 335-361.

Alvin Goldman (1979). What is Justified Belief? In George Pappas (ed.), Justification and Knowledge. Reidel, 1-24.

Alvin Goldman (2011). Toward a Synthesis of Reliabilism and Evidentialism? In Trent Dougherty (ed.), Evidentialism and its Discontents. Oxford University Press, 254-280.

John Hawthorne and Ofra Magidor (forthcoming). Reflections on Reasons. In Daniel Star (ed.), The Oxford Handbook of Reasons and Normativity. Oxford University Press.

Pamela Hieronymi (2011). Reasons for Action. Proceedings of the Aristotelian Society 111: $407-27$.

Jennifer Hornsby (2008). A Disjunctive Conception of Acting for Reasons. In Adrian Haddock \& Fiona Macpherson (eds.), Disjunctivism: Perception, Action, Knowledge. Oxford University Press, 244-261.

Thomas Kelly (2014). Evidence. In Edward Zalta (ed.), The Stanford Encyclopedia of Philosophy (Fall 2014 Edition), URL = $<$ http://plato.stanford.edu/archives/fall2014/entries/evidence/>.

Christos Kyriacou (2016). Metaepistemology. In J. Fieser and B. Dowden (eds.) Internet Encyclopedia of Philosophy, URL $=<\mathrm{http}: / / \mathrm{www}$.iep.utm.edu/meta-epi/ $>$.

Clayton Littlejohn (2012). Justification and the Truth-Connection. Oxford University Press Clayton Littlejohn (2013). XV—-the Russellian Retreat. Proceedings of the Aristotelian Society 113: 293-320, https://doi.org/10.1111/j.1467-9264.2013.00356.x

Susanne Mantel (2018). Determined by Reasons: A Competence Account of Acting for a Normative Reason. Routledge.

Kevin McCain (2014). Evidentialism and Epistemic Justification. Routledge.

Brian McLaughlin and Karen Bennett (2018). Supervenience. In Edward Zalta (ed.), The 
Stanford Encyclopedia of Philosophy (Spring 2018 Edition), URL = $<$ https://plato.stanford.edu/archives/spr2018/entries/supervenience/>.

Ram Neta (2008). What Evidence Do You Have? British Journal for the Philosophy of Science 59: 89-119.

Jonas Olson and Frans Svensson (2005). Regimenting Reasons. Theoria 61: 203-214.

Derek Parfit (2011). On What Matters. Oxford University Press.

Alvin Plantinga (1990). Justification in the Twentieth Century. Philosophy and Phenomenological Research 50: 45-71.

Eva Schmidt (2017a). New Trouble for "Reasons as Evidence": Means That Don't Justify the Ends. Ethics 127: 708-718.

Eva Schmidt (2017b). Possessing Epistemic Reasons. Philosophical Studies, https://doi.org/10.1007/s11098-017-1025-z.

Mark Schroeder (2008). Having Reasons. Philosophical Studies 139: 57-71.

Mark Schroeder (2015). Knowledge Is Belief for Sufficient (Objective and Subjective) Reason. In Tamar Szabó Gendler and John Hawthorne (eds.), Oxford Studies in Epistemology Vol. 5. Oxford University Press.

Sharon Street (2010). What is Constructivism in Ethics and Metaethics? Philosophy Compass 5: 363-384.

Kurt Sylvan (2014). On the Normativity of Epistemic Rationality. Dissertation. Rutgers University.

Kurt Sylvan (2015). What Apparent Reasons Appear to Be. Philosophical Studies 172: 587606.

Kurt Sylvan and Ernest Sosa (forthcoming). The Place of Reasons in Epistemology. In Daniel Star (ed.), The Oxford Handbook of Reasons and Normativity. Oxford University Press.

John Turri (2009). The Ontology of Epistemic Reasons, Nô̂s 43: 490-512.

Timothy Williamson (2000). Knowledge and Its Limits. Oxford University Press. 